\title{
Effects of Bioinoculants on Seedling Growth, Biochemical Changes and Nutrient Uptake of Erythrina Indica L. In Semi Arid Region of Southern India
}

Dr. Kuppurajendran*

Dr. Kuppurajendran, Assistant Professor, Research Centre in Botany, Tamilnadu, India

\section{Introduction}

Erythrina indica Lam. (Febaceae) is a deciduous armed tree, 10$20 \mathrm{~m}$ tall with $1 \mathrm{~m} \mathrm{dbh}$. It is a common plant with grayish with bark and coarse branches glabrous sparsely armed with short prickles found in India. It is known as kalyana murukku or mullu murunkkai in Tamil [1]. In siddha system, it is being considered useful for treating antihelmenthiasis, nematocidal and worm infection and also used as sedative and anti-inflammatory [2-4]. The presence of active constituents viz. alkaloids, glycosides, phenyl coumarin, proteins, carbohydrates, amino acids, steroids, tannins has been reported from root and seeds [5,6]. According to Harwell [7] seeds of Erythrina used in folk remedies for cancer, whose bark is used for fever, hepatitis, malaria, rheumatism, toothache also for boils and fractures. Fresh leaf paste is applied on the wounds of the cattle for healing [8]. Root is used for rheumatism, bark and leaves serve as a vermifuge [9].

Due to these advantages, Government and non-government organizations have planted avenue trees in the public land in urban area and highways. At present the pinch on fertilizer consumption is being felt more in India, since the country cannot afford to either import the required fertilizer at high cost and subsidize the sale to the farmers or build new fertilizer plants at formidable cost. Hence farmers are prepared to take to organic farming by using bio-inoculants. Bio-inoculants are cost effective and ecofriend natural inputs providing alternate source of plant nutrients, thus increasing farm income by providing extra yields and reducing input cost also. Bio-inoculants increase crop yield by 20 $30 \%$, replace chemical N \& P by $25 \%$, stimulate plant growth, activate soil biologically, restore natural fertility and provide protection against drought and some soil borne diseases. Of the bioinoculants widely used in agriculture crops. Azospirillum is an important non-symbiotic associative, nitrogen fixing rhizosphere bacteria and fixes atmospheric nitrogen in soil [10]. It augments nitrogen fixation [11]. Rice responds well to Azospirillum inoculation [12]. Further this bacterium is not yet known as a biocontrol agent of soil borne plant pathogen. However, some evidence shows that this activity has been overlooked. Azospirillum lipoferum produced catechol-typesiderophores under iron-starved conditions that exhibited antimicrobial activity against various bacterial and fungal isolates [13]. These inoculants need more attention in view of their triple action of nitrogen fixation, biocontrol and production of plant growth regulators. Phosphobacterium also produces auxin and gibberellin, which may have favorable effects on plant growth [14]. The stimulative effect of Phosphobacteria inoculation on plant growth in phosphorus deficient soil has been reported by Asea et al. [15]. Inoculation of Eucalyptus camaldulensis in an unsterilized soil with Phosphobacteria enhanced collar diameter, fresh weight and dry weight compared to uninoculated control [16]. In Leucaena leucocephala, an increase of $33.2 \%$ in plant height was observed following inoculation with Phosphobacteria [17]. Similarly, the Trichoderma strains also solubilize a number of poorly soluble nutrients $[18,19]$. However, in tree crops still it is at an experimental stage only.
The soil used for the production of planting stock in the forest nurseries is very low in nutrient and beneficial microbial population. Though the soil is mixed with farm yard manure (FYM), the quality of seedling is very poor due to insufficiency of desired microorganisms (many of the microorganisms are host specific) and the rate of mineralization and nitrogen fixation is very low, as a result the quality of the seedling is very poor. It is very difficult to establish in the initial stage in the field with these seedlings. This problem can be overcome by providing suitable biofertilizers. It has been already reported that the use of biofertilizers results in better growth and nutrient uptake in seedlings. Plants colonized by mycorrhizal fungi are better adapted to withstand drought in the nursery and field by phosphorus mediated system. Phosphobacterium will solubilize Phosphorus insoluble forms of phosphate and they help plants to absorb and translocate more soluble phosphate [20]. Nitrogen fixing bacteria of genus Azospirillum have promoted tree growth [21]. Similarly, bioinoculants improve the quality of tree seedlings of Casuarina equisetifolia [22], Moringa oleifera [23], Acacia nilotica [24], Azadirachta indica [25] and Delonix regia [26]. However, the efficiency of individual and combined inoculation of biofertilizers in the Erythrina seedlings needs to be studied. Hence, the present study was undertaken to find out the compatibility of different biofertilizers and their augmentation effect of quality seedling production of Erythrina.

\section{Materials and Methods}

\section{Seeds}

Erythrina fruits were collected from a single tree, located at the semi arid region of Karaikudi in Sivagangai district of Tamil Nadu, India. Seeds were separated and graded and uniform size was used for raising seedlings. Seedlings were raised in a mixture of unsterilized sand: Red soil: Farm Yard Manure (2: 1: 1) in polythene bag (Plate1-4). In order to find out suitable bio-inoculants and their combinations to achieve maximum overall growth and minimise the cost of seedling production of the following treatments were given seven days after germination.

\section{Azospirillum and phosphobacterium}

Lignite based carrier culture of Azospirillum (Azospirillum brasilense) and Phosphobacterium (Bacillus megaterium var.

${ }^{*}$ Corresponding author: Dr. Kuppurajendran, Assistant Professor, Research Centre in Botany, Thiagarajar College (Autonomous), 139-140, Kamarajar Salai, Teppakulam (PO), Madurai - 625 009, Tamilnadu, India, E- mail: kuppurajendran@rediffmail.com

Received February 27, 2012; Accepted March 23, 2012; Published March 23, 2012

Citation: Kuppurajendran (2012) Effects of Bioinoculants on Seedling Growth, Biochemical Changes and Nutrient Uptake of Erythrina Indica L. In Semi Arid Region of Southern India. J Biomet Biostat 3:134. doi:10.4172/2155-6180.1000134

Copyright: (c) 2012 Kuppurajendran. This is an open-access article distributed under the terms of the Creative Commons Attribution License, which permits unrestricted use, distribution, and reproduction in any medium, provided the original author and source are credited. 
Citation: Kuppurajendran (2012) Effects of Bioinoculants on Seedling Growth, Biochemical Changes and Nutrient Uptake of Erythrina Indica L. In Semi Arid Region of Southern India. J Biomet Biostat 3:134. doi:10.4172/2155-6180.1000134

phosphoticum) with a population load of $10^{9}$ and $10^{8}$ colony forming units / gram of peat soil respectively were obtained from the Department of Agricultural Microbiology, Tamil Nadu Agricultural University, Coimbatore, Tamil Nadu, India.

\section{AM fungi}

AM fungus (Glomus fasciculatum) was isolated and recorded as dominant species in the rhizosphere soil of Erythrina. It was multiplied in pot culture in the sterilized mixture of sand: soil (1: 1 $\mathrm{v} / \mathrm{v}$ ) and maintained in the roots of Sorghum vulgare as the host plant. The inoculum contained extrametrical hyphae, chlamydospores and infected root segments were added in the root zones of each seedling.

\section{Treatment}

Seedlings were raised in $13 \times 26 \mathrm{~cm}$. size polyethylene bags with a potting mixture of unsterilized sand: red soil: farm yard manure (2: 1: 1). Seven days after germination in polyethylene bags 10 grams of peat soil based culture of Azospirillum, Phosphobacterium and AM fungus were inoculated by making holes in the rhizosphere of seedlings.

$\mathrm{T}_{1}$ - Azospirillum (Azospirillum brasilense)

$\mathrm{T}_{2}$-Phosphobacterium (Bacillus megaterium var. phosphoticum)

$\mathrm{T}_{3}$ - Arbuscular Mycorrhizal Fungi (AMF) (Glomus fasciculatum)

$\mathrm{T}_{4}$ - Azospirillum + Phosphobacterium

$\mathrm{T}_{5}-$ Azospirillum $+\mathrm{AMF}$

$\mathrm{T}_{6}$ - Phosphobacterium $+\mathrm{AMF}$

$\mathrm{T}_{7}$ - Azospirillum + Phosphobacterium + AMF

$\mathrm{T}_{8}$ - Control (Sand: Red soil: Farm Yard Manure 2:1:1)

\section{Experimental design}

Nursery experiment was conducted at the Department of Rural Development, Alagappa University, Karaikudi, Tamil Nadu, India. The experiment was set up in a completely randomized block design with 8 treatments and twenty four replicates. All the plants were kept under identical nursery condition up to 120 days.

Seedling survival percentage was calculated using the following formula:

Seedling survival percentage $=$

Number of seedlings present in each treatmen

Total number of seedlings transplanted in each treatment

\section{Harvesting and measurement}

120 days after transplanting from each treatment, a total of 12 seedlings were randomly selected and height and basal diameter were recorded. Seedlings were carefully uprooted without disturbing the root system and washed in running tap water. Excess of water was wiped out by placing them between folds of blotting paper. The seedlings were cut at collar region, dried separately at $70^{\circ} \mathrm{C}$ in paper bags in hot air oven and biomass estimation (root and shoot dry weight) was carried out using top pan electronic balance.

\section{Assessment of mycorrhizal infection}

Mycorrhizal root infection was assessed following the procedure of Phillips and Hayman [27]. The root segments were placed in a $2.5 \%$ aqueous solution of $\mathrm{KOH}(\mathrm{w} / \mathrm{v})$ and boiled in a water bath at $90^{\circ} \mathrm{C}$ for 15 minutes. The roots were rinsed in water and lightened in $\mathrm{H} 2 \mathrm{O} 2$ (3 $\mathrm{ml}$ of $20 \% \mathrm{NH} 4 \mathrm{OH}$ in $30 \mathrm{ml} \mathrm{H} 2 \mathrm{O} 2$ ) for $10-45$ minutes. They were again thoroughly rinsed with water several times and acidified by soaking in
$40-50 \mathrm{ml}$ of $1 \% \mathrm{HCl}$ for $3 \mathrm{~min}$. Acidified roots were stained in an acidic glycerol solution ( $500 \mathrm{ml}$ glycerol, $450 \mathrm{ml} \mathrm{H} 2 \mathrm{O}, 50 \mathrm{ml} \mathrm{1 \%} \mathrm{HCl}$ ) containing $0.05 \%$ trypan blue. The trypan blue solution was poured off and the roots were de-stained in acidic glycerol at room temperature. The stained roots were mounted in a glass slide and percentage of infection was calculated.

Seedlings quality index

Seedlings Quality Index was calculated using the formula of Dickson et al. [28].

Seedlings Quality Index (SQI)

\begin{tabular}{lc} 
Total weight $(\mathrm{g} /$ plant $)$ \\
\hline Height $(\mathrm{cm})$ & Shoot weight $(\mathrm{g} /$ plant $)$ \\
Root collar diameter $(\mathrm{mm})$ & Root weight $(\mathrm{g} /$ plant $)$
\end{tabular}

\section{Nutrient analysis}

Plant samples were taken for the bio-chemical analysis. The ovendried plant samples were ground to pass through a 0.5 millimeter plastic sieve before digestion.

\section{Nitrogen and phosphorous}

The dried plant material was ground in a mortar and pestle and the total nitrogen content was estimated by the conventional microKjeldahl method [29]. Total phosphorus was estimated by the method of Fiski-Subba-Rao as modified by Bartlett [30].

\section{Estimation of total potassium, calcium and magnesium}

1 gram of plant sample was digested with tri-acid mixture with $\mathrm{HNO}_{3}: \mathrm{H}_{2} \mathrm{SO}_{4}: \mathrm{HClO}_{4}$ in the ratio of 9:2:1 until it became colorless. After digestion it was filtered and the volume was made up to $100 \mathrm{ml}$. Potassium in the extract was determined using a flame photometer [31]. Calcium and Magnesium were determined by the Versenate method as described by Jackson [31].

\section{Estimation of chlorophyll and protein}

Chlorophyll-a, chlorophyll-b and total chlorophyll content was estimated by the method of Yoshida et al. [32] and total protein by Lowry et al.[33].

\section{Statistical analysis}

The data were statistically analyzed by analysis of variance (ANOVA) and treatment means were separated using Duncan's Multiple Range Test $(\mathrm{P}<0.05)$ [34].

\section{Results}

\section{Seedling survival}

$100 \%$ germination and survival was recorded in E. indica seedlings in the nursery condition. Statistically, there is no variation between microbial inoculants seedlings and control (Table 1).

\section{Shoot length, root length and basal diameter}

Significant differences in shoot length, root length and basal diameter were recorded in E. indica seedlings inoculated with the different microbial inoculants compared to the uninoculated control (Plate 2) (Table 1). 
Citation: Kuppurajendran (2012) Effects of Bioinoculants on Seedling Growth, Biochemical Changes and Nutrient Uptake of Erythrina Indica L. In Semi Arid Region of Southern India. J Biomet Biostat 3:134. doi:10.4172/2155-6180.1000134

\section{Shoot length}

From the analysis of growth data the individual inoculation of Azospirillum $\left(\mathrm{T}_{\mathrm{s}}\right)$ treated seedlings was found to be the most effective in increasing the growth and biomass. Among all the treatments, the individual inoculation with Azospirillum ( $\mathrm{T}_{1}$ ) recorded maximum shoot length increase $(57.71 \%)$ over the control followed by combined inoculation of Azospirillum + Phosphobacterium ( $\mathrm{T}_{4}$ ) with $45.00 \%$ increase over control, 120 days after inoculation (Table 1).

\section{Root length}

Significant differences in root length were recorded in E. indica seedlings inoculated with different microbial inoculants compared to the uninoculated control (Table 1). From the analysis of growth data, the individual inoculation of Azospirillum $\left(\mathrm{T}_{1}\right)$ was found to be the most effective in increasing the root length of seedlings.

Among all the treatments, the individual inoculation with Azospirillum $\left(\mathrm{T}_{1}\right)$ showed maximum root length $15.82 \mathrm{~cm}(41.76 \%$ increase over the control). The combined inoculation of Azospirillum + Phosphobacterium+ AMF $\left(\mathrm{T}_{7}\right)$ showed higher root length and was statistically on a par with Azospirillum + Phosphobacterium $\left(\mathrm{T}_{4}\right)$ inoculated seedlings.

\section{Basal diameter}

Azospirillum $\left(\mathrm{T}_{1}\right)$ inoculated seedlings showed for better growth than other single treatment ( $74.54 \%$ increases over the control). The combined inoculation of Azospirillum + Phosphobacterium + AMF $\left(\mathrm{T}_{7}\right)$ showed significantly higher growth statistically on a par with Azospirillum $\left(\mathrm{T}_{1}\right)$ inoculated seedlings. Among the double inoculation Azospirillum + Phosphobacterium $\left(\mathrm{T}_{4}\right)$, Azospirillum $+\operatorname{AMF}\left(\mathrm{T}_{5}\right)$ and Phosphobacterium + AMF (T6) registered higher levels of basal diameter. Phosphobacterium $\left(\mathrm{T}_{2}\right)$ and $\operatorname{AMF}\left(\mathrm{T}_{3}\right)$ inoculated seedlings showed similar growth over other treatments (Table 1).

\section{Shoot biomass}

The data pertaining to dry matter accumulation of shoot, root and total biomass are presented in Table 2. Significant differences were observed among the treatments evaluated 120 days after inoculation. The highest biomass in the shoot was recorded in seedlings inoculated with Azospirillum + Phosphobacterium +AMF $\left(\mathrm{T}_{7}\right)$. It was statistically on a par with seedlings treated with Azospirillum $\left(\mathrm{T}_{1}\right)$. They registered $71.30 \%$ and $61.55 \%$ increase over control (Table 2).

\section{Root biomass}

Statistically highly significant difference was found in different type of microbial inoculation on root biomass of Erythrina seedlings. Inoculation of Azospirillum $\left(\mathrm{T}_{1}\right)$ alone and in combination with other inoculants was found to significantly increase root biomass when compared to other treatments. Root biomass was highest in Azospirillum $\left(\mathrm{T}_{1}\right)$ followed by Azospirillum + Phosphobacterium + $\operatorname{AMF}\left(\mathrm{T}_{7}\right)$ (Table 2).

\section{Total biomass of seedling}

Seedling biomass was the highest in the Azospirillum $\left(\mathrm{T}_{1}\right)$ treated seedlings and it was $65.23 \%$ more than that of the control and it was statistically on a par with seedlings treated with Azospirillum + Phosphobacterium $+\mathrm{AM}\left(\mathrm{T}_{7}\right)$. In the dual inoculation seedlings inoculated in combination with Azospirillum recorded more biomass than the control (Table 2).

\section{Seedling quality index}

Good quality seedlings were obtained from seedlings inoculated with Azospirillum $\left(\mathrm{T}_{1}\right)$. Azospirillum + Phosphobacterium + AMF $\left(\mathrm{T}_{7}\right)$ showed the next highest seedling quality index, followed by Azospirillum + Phosphobacterium $+\left(\mathrm{T}_{5}\right)$. Among the double inoculations Azospirillum + AMF $\left(\mathrm{T}_{5}\right)$ showed the highest seedling quality index (Figure $1 \&$ Table 2).

\begin{tabular}{|c|c|c|c|c|c|}
\hline Treatments & Seed Germination (\%) & Collar diameter $\left(\mathrm{mm}\right.$ plant $\left.^{-1}\right)$ & Shoot height (cm plant ${ }^{-1}$ ) & Root height (cm plant ${ }^{-1}$ ) & Total height (cm plant ${ }^{-1}$ ) \\
\hline $\mathrm{T}_{1}$ & 100.00 & $1.112^{\mathrm{e}}$ & $40.20^{f}$ & $15.82^{\mathrm{e}}$ & $56.02^{\mathrm{e}}$ \\
\hline $\mathrm{T}_{2}$ & 100.00 & $0.893^{c}$ & $30.00^{\mathrm{b}}$ & $12.16^{b}$ & $42.16^{c}$ \\
\hline $\mathrm{T}_{3}$ & 100.00 & $0.779^{b}$ & $26.29^{a}$ & $12.18^{b}$ & $38.47^{b}$ \\
\hline $\mathrm{T}_{4}$ & 100.00 & $0.831^{\mathrm{c}}$ & $36.96^{e}$ & $14.03^{\mathrm{cd}}$ & $50.99^{d}$ \\
\hline$T_{5}$ & 100.00 & $0.783^{b}$ & $31.74^{c}$ & $13.29^{c}$ & $45.03^{\text {cd }}$ \\
\hline $\mathrm{T}_{6}$ & 100.00 & $0.989^{d}$ & $26.32^{\mathrm{a}}$ & $12.32^{\mathrm{b}}$ & $38.64^{b}$ \\
\hline $\mathrm{T}_{7}$ & 100.00 & $0.894^{c}$ & $35.31^{d}$ & $14.49^{d}$ & $49.80^{d}$ \\
\hline $\mathrm{T}_{8}$ & 100.00 & $0.663^{\mathrm{a}}$ & $25.49^{a}$ & $11.16^{\mathrm{a}}$ & $36.65^{\mathrm{a}}$ \\
\hline
\end{tabular}

Means followed by a common letter(s) in the same column are not significantly different at the $5 \%$ level by DMRT

Treatments: $\mathrm{T}_{1}$ - Azospirillum; $\mathrm{T}_{2}$ - Phosphobacterium; $\mathrm{T}_{3}$ - AMF; $\mathrm{T}_{4}-$ Azospirillum + Phosphobacterium; $\mathrm{T}_{5}-$ Azospirillum+ AMF; $\mathrm{T}_{6}-\mathrm{Phosphobacterium} \mathrm{+} \mathrm{AMF;} \mathrm{T}_{7}-$ Azospirillum + Phosphobacterium + $\mathrm{AMF}^{2} ; \mathrm{T}_{8}$-Control

Table 1: Impact of bioinoculants on the seed germination and growth of Erythrina indica seedlings.

\begin{tabular}{|c|c|c|c|c|c|}
\hline Treatments & Shoot dry weight (gram/ plant $^{-1}$ ) & Root dry weight (gram/ plant $^{-1}$ ) & Total dry weight (gram/ plant $^{-1}$ ) & Seedling quality index & AM fungal colonization (\%) \\
\hline $\mathrm{T}_{1}$ & $12.10^{f}$ & $6.67^{\mathrm{d}}$ & $18.77^{\mathrm{f}}$ & 0.360 & 13 \\
\hline $\mathrm{T}_{2}$ & $7.63^{b}$ & $4.02^{\mathrm{a}}$ & $11.65^{\mathrm{b}}$ & 0.237 & 14 \\
\hline $\mathrm{T}_{3}$ & $7.49^{b}$ & $4.13^{a}$ & $11.62^{\mathrm{b}}$ & 0.227 & 43 \\
\hline $\mathrm{T}_{4}$ & $11.09^{\mathrm{e}}$ & $4.90^{\mathrm{b}}$ & $15.99^{e}$ & 0.251 & 12 \\
\hline $\mathrm{T}_{5}$ & $10.13^{d}$ & $4.69^{b}$ & $14.82^{\mathrm{d}}$ & 0.248 & 35 \\
\hline $\mathrm{T}_{6}$ & $8.50^{\circ}$ & $3.71^{\mathrm{a}}$ & $12.21^{\mathrm{c}}$ & 0.295 & 33 \\
\hline $\mathrm{T}_{7}$ & $12.83^{f}$ & $5.96^{c}$ & $18.79^{f}$ & 0.325 & 62 \\
\hline $\mathrm{T}_{8}$ & $6.23^{a}$ & $3.87^{a}$ & $9.00^{a}$ & 0.158 & 8 \\
\hline
\end{tabular}

Means followed by a common letter(s) in the same column are not significantly different at the $5 \%$ level by DMRT

Treatments: $\mathrm{T}_{1}$ - Azospirillum; $\mathrm{T}_{2}$ - Phosphobacterium; $\mathrm{T}_{3}$ - AMF $; \mathrm{T}_{4}-$ Azospirillum + Phosphobacterium; $\mathrm{T}_{5}-$ Azospirillum + AMF; $\mathrm{T}_{6}-\mathrm{Phosphobacterium} \mathrm{+} \mathrm{AMF;} \mathrm{T}_{7}-$ Azospirillum + Phosphobacterium + AMF; $\mathrm{T}_{8}$ - Control

Table 2: Impact of bioinoculants on the dry matter production and seedling quality index of Erythrina indica seedlings. 
Citation: Kuppurajendran (2012) Effects of Bioinoculants on Seedling Growth, Biochemical Changes and Nutrient Uptake of Erythrina Indica L. In Semi Arid Region of Southern India. J Biomet Biostat 3:134. doi:10.4172/2155-6180.1000134

Page 4 of 6

\section{Mycorrhizal infection}

Mycorrhizal infection was found only in seedlings inoculated with AM fungi and the combined inoculation of Azospirillum + Phosphobacterium $+\operatorname{AMF}\left(\mathrm{T}_{7}\right)$ showed higher levels of infection followed by AMF $\left(\mathrm{T}_{3}\right)$ inoculated seedlings (Plate 3 \& Table 2).

\section{Total chlorophyll content}

Total chlorophyll content was found to be maximum in the seedlings inoculated with Azospirillum ( $4.650 \mathrm{mg} / \mathrm{g}$ fresh weight of leaves) followed by Azospirillum + Phosphobacterium + AMF (3.49 $\mathrm{mg} / \mathrm{g}$ fresh weight of leaves) (Table 3).

\section{Protein content}

Among all the treatments, protein content in tissue of Erythrina seedlings was found to be maximum in the seedlings produced from single application of Azospirillum ( $0.048 \mathrm{mg} / \mathrm{plant})$ and triple application of Azospirillum + Phosphobacterium + AMF $(0.075 \mathrm{mg} /$

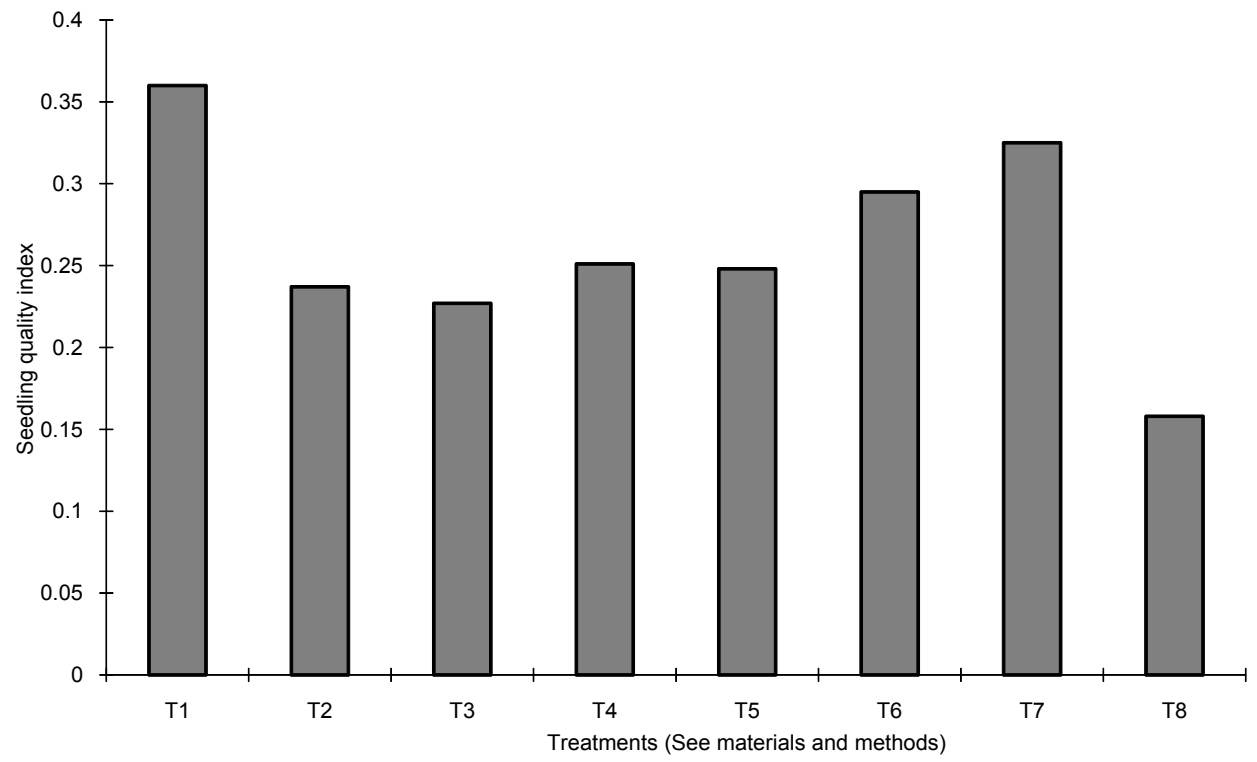

Figure 1: Seedling quality index of Erythrina indica inoculated biofertilizers.

\begin{tabular}{|c|c|c|c|c|}
\hline Treatments & Protein (mg/ gram fresh weight) & Chlorophyll a (mg/g fresh weight) & Chlorophyll b (mg/g fresh weight) & Chlorophyll b (mg/g fresh weight) \\
\hline $\mathrm{T}_{1}$ & 0.04884 & 1.06576 & 0.81452 & 1.88028 \\
\hline $\mathrm{T}_{2}$ & 0.03996 & 0.94988 & 0.61456 & 1.56444 \\
\hline $\mathrm{T}_{3}$ & 0.03108 & 0.81484 & 0.68748 & 1.50232 \\
\hline $\mathrm{T}_{4}$ & 0.05328 & 1.0466 & 0.9874 & 2.03400 \\
\hline $\mathrm{T}_{5}$ & 0.06216 & 1.02744 & 0.9798 & 2.00724 \\
\hline $\mathrm{T}_{6}$ & 0.06660 & 0.94332 & 0.76024 & 1.70356 \\
\hline $\mathrm{T}_{7}$ & 0.07548 & 1.0592 & 0.8602 & 1.9194 \\
\hline $\mathrm{T}_{8}$ & 0.02222 & 0.9151 & 0.5156 & 1.4307 \\
\hline
\end{tabular}

Treatments: $\mathrm{T}_{1}$ - Azospirillum; $\mathrm{T}_{2}$ - Phosphobacterium; $\mathrm{T}_{3}-\mathrm{AMF} ; \mathrm{T}_{4}-$ Azospirillum + Phosphobacterium; $\mathrm{T}_{5}-$ Azospirillum + AMF; $\mathrm{T}_{6}-\mathrm{Phosphobacterium} \mathrm{+} \mathrm{AMF} ; \mathrm{T}_{7}-$ Azospirillum + Phosphobacterium + AMF; $\mathrm{T}_{8}$ - Control

Table 3: Impact of bioinoculants on chlorophyll and protein content (mg / plant) of Erythrina indica seedlings.

\begin{tabular}{|c|c|c|c|c|c|c|}
\hline Treatments & Biomass (gram/plant ${ }^{-1}$ ) & N (\%) & $\mathbf{P}(\%)$ & K (\%) & $\mathrm{Ca}(\%)$ & Mg (\%) \\
\hline $\mathrm{T}_{1}$ & $18.77^{f}$ & $2.13 c(0.399)$ & $0.108 c(0.020)$ & $1.423 \mathrm{~d}(0.267)$ & $1.540 f(0.289)$ & $0.49 c(0.091)$ \\
\hline $\mathrm{T}_{2}$ & $11.65^{b}$ & $2.00 \mathrm{~b}(0.233)$ & $0.103 b(0.011)$ & $1.400 \mathrm{~b}(0.163)$ & $1.423 c(0.165)$ & $0.40 b(0.046)$ \\
\hline $\mathrm{T}_{3}$ & $11.62^{\mathrm{b}}$ & $2.00 \mathrm{~b}(0.232)$ & $0.103 b(0.011)$ & $1.400 \mathrm{~b}(0.162)$ & $1.340 b(0.155)$ & $0.41 b(0.047)$ \\
\hline $\mathrm{T}_{4}$ & $15.99^{e}$ & $2.10 \mathrm{bc}(0.335)$ & $0.108 \mathrm{c}(0.017)$ & $1.403 b(0.224)$ & $1.432 \mathrm{c}(0.228)$ & $0.43 b(0.068)$ \\
\hline $\mathrm{T}_{5}$ & $14.82^{\mathrm{d}}$ & $2.10 \mathrm{bc}(0.311)$ & $0.103 b(0.015)$ & $1.402 b(0.207)$ & $1.447 d(0.214)$ & $0.41 b(0.060)$ \\
\hline $\mathrm{T}_{6}$ & $12.21^{\mathrm{c}}$ & $2.00 \mathrm{~b}(0.244)$ & $0.108 c(0.013)$ & $0.405 b(0.171)$ & $1.500 \mathrm{e}(0.183)$ & $0.46 c(0.056)$ \\
\hline $\mathrm{T}_{7}$ & $18.79^{f}$ & $2.15 c(0.404)$ & $0.107 \mathrm{c}(0.020)$ & $1.416 \mathrm{c}(0.266)$ & $1.502 \mathrm{e}(0.282)$ & $0.46 c(0.086)$ \\
\hline $\mathrm{T}_{8}$ & $9.00^{\mathrm{a}}$ & $1.89 a(0.170)$ & $0.099 a(0.009)$ & $1.225 a(0.110)$ & $1.235 a(0.111)$ & $0.37 a(0.033)$ \\
\hline
\end{tabular}

Means followed by a common letter(s) in the same column are not significantly different at the $5 \%$ level by DMRT

Figures are parentheses and nutrient uptake (g/plant)

Treatments: $\mathrm{T}_{1}$ - Azospirillum; $\mathrm{T}_{2}$ - Phosphobacterium; $\mathrm{T}_{3}$-AMF; $\mathrm{T}_{4}$ - Azospirillum + Phosphobacterium; $\mathrm{T}_{5}$ - Azospirillum+AMF; $\mathrm{T}_{6}$ - Phosphobacterium + AMF; $\mathrm{T}_{7}$ - Azospirillum + Phosphobacterium + AMF; $\mathrm{T}_{8}$-Control

Table 4: Dry matter production, nutrient concentration (\%) and nutrient uptake (mg/plant) of Erythrina indica seedlings inoculated with biofertilizers in nursery condition . 
Citation: Kuppurajendran (2012) Effects of Bioinoculants on Seedling Growth, Biochemical Changes and Nutrient Uptake of Erythrina Indica L. In Semi Arid Region of Southern India. J Biomet Biostat 3:134. doi:10.4172/2155-6180.1000134

plant) followed by Phosphobacterium + AMF (0.066mg/plant) treatment (Table 3).

\section{Nutrient uptake}

Nutrient concentration in plant tissue and nutrient uptake of was higher in seedling inoculated with Azospirillum ( $\mathrm{T}_{1}$ ) treated seedlings and it was statistically on a par with triple inoculation of Azospirillum + Phosphobacterium + AMF. Among all the treatments, the individual inoculation with Azospirillum $\left(\mathrm{T}_{1}\right)$ recorded as $12.85 \%$ of $\mathrm{N}, 9 \%$ of $\mathrm{P}$, $16 \%$ of $\mathrm{K} 24 \%$ of $\mathrm{Ca}$ and $32 \%$ of $\mathrm{Mg}$ was higher than that of control. Similarly, higher percentage of seedling inoculated with Azospirillum + Phosphobacterium + AMF (Table 4).

\section{Discussion}

Biologically active products, more appropriately called microbial inoculations, containing active strains of a selective microorganisms like Azospirillum, Phosphobacterium, Arbuscular mycorrhizae alone or in combination, help plant growth through different mechanisms, including biological nitrogen fixation and solubilization of insoluble phosphate fertilizer. In the present study, the height, diameter and dry matter and quality seedlings were higher in the Erythrina seedlings inoculated with bioinoculants. The increase of growth may be attributed to high accumulation of chlorophyll and protein in the plant tissue.

Nitrogen fixing bacteria of the genus Azospirillum have promoted plant growth of agronomically important field crops by 10 to $30 \%$ in the field experiment $[35,36]$ crop yield increase in germination rate, plant height, leaf size [37] enhanced minerals and water uptake, increased dry matter accumulation, root surface area, root diameter density and root hair [38] to support the earlier reports. In the present study, Azospirillum inoculated seedlings showed better growth and root biomass when compared to the control. Growth may be attributed due to increased root biomass and accumulation of nitrogen [39], and the production of gibberellins and cytokinin like substances [40] which promote the growth of the seedlings. The above results corroborate with earlier studies on quality seedling production of Casuarina equisetifolia [22], Moringa oleifera [23], Acacia nilotica [24] Delonix regia [26].

Growth promoting effect of inoculation with Azospirillum and Phosphobacterium alone or dual inoculation with both non symbiotic biofertilizers was found in several tree species such as Casuarina $[22,41]$ Casuarina trees treated in farm forestry [42] Moringa oleifera [23]. In the present study Phosphobacterium inoculated seedlings produced better plant height, stem girth and total biomass. It may be due to inoculation of phosphate solubilizing microorganism Bacillus megaterium which has shown stable and consistent capacity to solubilize insoluble phosphorus and thus making it available to plants.

Phosphate plays a major role in the root development [43]. Stribley [44] reported that $\mathrm{P}$ seems to be the most important nutrient involved, other nutrients such as $\mathrm{N}, \mathrm{P}, \mathrm{K}, \mathrm{Ca}$, and $\mathrm{Mg}$ are translocated along with $\mathrm{AM}$ hyphae. Inoculation with $\mathrm{AM}$ fungi is known to enhance plant growth by improving the mineral nutrient of the host plant [45]. In the present study mycorrhizal infection in roots of seedlings were found only in the inoculated seedlings. It is also recorded that growth medium needs bioinoculants and AMF inoculated seedlings had improved growth and nutrient content especially $\mathrm{P}$ uptake in the present result corroborate with earlier reports by Verma and Jamaluddin [46]. And seedlings treated with AM fungi on Azadiracta indica, Rajendran et al. [22] in Casuarina equisetifolia, Rajendran and Jayasree [24] in Acacia nilotica, Meenakshisundaram et al. [26] in Delonix regia. This can be attributed to the increased absorbing surface area due to extensive external network of mycelium produced by the VAM fungi in association with the host root system [47].

In the present study dual inoculation of AMF with Phosphobacterium influence the growth and biomass of Erythrina seedlings. It is relevant to mention here that Phosphobacterium by virtue of its capacity to multiply certain growth promoting substances like IAA and GA might induce the growth of Erythrina seedlings $[48,49]$. Among all the treatments are combined inoculations of Azospirillum + Phosphobacterium +AMF produced excellent growth, biomass and tissue nutrient concentration. The greater height, diameter and dry matter of the Erythrina seedlings due to co-inoculation of all the biofertilizers might strongly improve accumulation of nitrogen due to Azospirillum [50], more phosphorus uptake by Phosphobacterium [43] and VAM fungi [51].

The total chlorophyll and soluble protein content was found to be maximum in the seedlings inoculated with Azospirillum. This increase is in agreement with other findings [52] and was attributed [53] to the greater supply of nitrogen to growing tissues. Similarly increase in chlorophyll and soluble protein content was also recorded in shola species [54] with inoculation of Azospirillum + Phosphobacterium.

\section{Conclusion}

Increasing dry land farming and development technologies for arid lands with soil related constraints now acquire new importance and emerge as new frontiers for agricultural and farm forestry development. Increased agro and farm forestry production has to come through the adoption of better management technology. Long-term sustainability in agriculture and forestry is possible only through the use of low cost farm grown inputs, which work in harmony with nature. Biofertilizers act as perpetually renewable inputs helping in better tree crop nutrient management and maintenance of soil health, better soil and water management leading to improved forestry practices. It is inferred that under appropriate technology, the use of efficient microbial inoculants yield increased growth and biomass of Erythrina seedlings. The present study clearly shows that the application of Azospirillum plays a significant role in increasing the growth response of Erythrina seedlings in a stipulated period, thereby producing good quality planting stock. These treated seedlings may perform better in nutrient impoverished soil too.

\section{Reference}

1. Vaidyaratnam KS (1998) Murugesa Mudaliyar Siddha Materia Medica. 248.

2. Ratnasooriya WD, Dharmasiri MG (1999) Aqueous extract of srilankan Erythrina indica leaves has sedative but not analgesic activity. Fitoterapia 70: 311-313.

3. Jayakumari S, Ravichandiran V, Karthik J, Deepa N, Anbu J, et al. (2009) AntiInflammatory Activity of Erythrina Indica Linn. Leaves 5: 56.

4. Verma NS, Gupta P (2011) Investigation of anthelmintic activity of polyherbal preparation. IJPLS 2: 590-591.

5. Ecobichon DJ (1997) The Basis of Toxicology Testing. CRC Press, New York.

6. Lausell S (1966) Scrum triglyceride estimation. Scand J Clin Lab Invest 18 668-670.

7. Hartwell JL (1969) Plants used against cancer. A survey. Lloydia 32: 78-107.

8. Rajendran K, Balaji P, Jothi BM (2008) Medicinal plants and their utilization by villagers in southern districts of Tamil Nadu. Indian Journal of Traditional Knowledge 7: 417-420.

9. List PH, Horhammer L (2008) 1969-1979 Hager's handbuch der pharmazeutischen praxis.Vols 2-6 Springer-Verlag, Berlin.

10. Krishnamoorthy G (2002) Agrolook. Editor, Usha printers, New Delhi, 22-24. 
Citation: Kuppurajendran (2012) Effects of Bioinoculants on Seedling Growth, Biochemical Changes and Nutrient Uptake of Erythrina Indica L. In Semi Arid Region of Southern India. J Biomet Biostat 3:134. doi:10.4172/2155-6180.1000134

11. Vijayakumari B, Janardhanan K (2003) Effect of biofertilizers on seed germination, seedling growth and biochemical changes in silk cotton [Ceiba pentanndra (Linn.) Gaertn.].Crop Research 25: 328-332.

12. Karthikeyan S, Anthoni Raj S, Prabakaran J (2003) Role of Biofertilizers in crop plants. Agrobios Newsletter 2: 11-12.

13. Shah S, Karkhanis V, Desai A (1992) Isolation and characterization of siderophore, with antimicrobial activity, from Azospirillum lipoferum M. Curr microbiol 25: 347-351.

14. Somani LL, Bhandari SC, Sexena SN, Gulati IJ (1990) PhosphomicroorgansimsBiofertilizers (Eds) Somani LL, Bhandari SC, Sexena SN, Vyas KK, 271-294.

15. Asea PEA, Kucey RMN, Stewart JWB (1988) Inorganic phosphate solubilization by two penicillium species in solution culture and soil. Soil Biol Biochem 20: 459-464.

16. Ohammad G, Ramprasad (1988) Influence of microbial fertilizer on biomass accumulation in polypotted E. camaldulensis seedlings. Journal of Tropical Forestry 4: 74-77.

17. Young CC (1990) Effects of phosphorus-solubilizing bacteria and vesiculararbuscular mycorrhizal fungi on the growth of tree species in subtropicaltropical soils. Soil sci and plant nutr 36: 225-231.

18. Altomare C, Norvell WA, Bjorkman T, Harman GE (1999) Solubilization of phosphates and micronutrients by the plant growth promoting and biocontro fungus Trichoderma harzianum Rifai 1295-22. Appl Environ Microbiol 65: 29262933.

19. Harman GE (2000) Myths and dogmas of biocontrol, changes in percecption derived from research on Trichoderma harzianum T-22. Plant Disease 84: 377-393.

20. Azcon R, Barea JM, Hayman DS (1976) Utilization of rock phosphate in alkaline soils by plants inoculated with mycorrhizal fungi and phosphate- solubilizing bacteria. Soil Biol Biochem 8: 135-138.

21. Wong PP, Sternberg NE (1979) Characterization of Azospirillum isolates from nitrogen fixing roots of harvested Sorghum plants. Appl Environ Microbiol 38 : 1189-1191.

22. Rajendran K, Sugavanam V, Devaraj P (2003) Effect of microbial inoculation on quality seedling production of Casuarina equisetifolia. Journal of Tropical Forest Science 15: 82-96.

23. Kasthuri Rengamani S, Jothibasu M, Rajendran K (2006) Effect of bioinoculants on quality seedlings production of Drumstick (Moringa oleifera $\mathrm{L}$ ). Journal of Non-Timber Forest Products 13: 41-46.

24. Rajendran K, Jayashree (2007) Effect of biofertilizers on quality seedling production of Acacia nilotica. Journal of Non-timber forest products 14: 1-5.

25. Alagesaboopathi C, Rajendran K (2009) Effect of biofertilizers on quality seedling production of Azadirachta indica (A.) Juss. Journal of Phytological Research 22: 125-130.

26. Meenakshisundaram M, Santhaguru K, Rajendran K (2011) Effects of Bioinoculants on quality seedling production of Delonix regia in tropical nursery conditions. Asian Journal of Biochemical and Pharmaceutical Research 1: 99107

27. Phillips JM, Hayman DS (1970) Improved procedures for clearing roots and staining parasite and vesicular Arbuscular mycorrhizal fungi for rapid assessment of infection. Transaction of British Mycological Society 55: 158161.

28. Dickson A, Leaf AL, Hosner JF (1960) Quality Appraisal of White Spruce And White Pine Seedling Stock In Nurseries. Forest chronicle 36: 10-13.

29. Umbriet WW, Burris RH, Stauffer IF (1972) Methods for nitrogen. Manometric and Biochemical Techniques (5th edn), Burgess publishing company, Minneosta.

30. Bartlett GR (1959) Phosphorous assay in column chromatography. J Biol Chem 234: 466-468.

31. Jackson ML (1973) Soil chemical analysis. Printice Hall of India (Pvt) Ltd., New Delhi.

32. Yoshida S, Forno DA, Cock JH (1971) Laboratory Manual for physiological studies of Rice. IRRI publication, Philippines.
33. Lowry OH, Rosebrough NJ, Farr AL, Randall RJ (1951) Protein measurement with the Folin phenol reagent. J Biol Chem 193: 265.

34. Duncan DB (1955) Multiple range and multiple f-tests. Biometrics 11: 1-42.

35. Okon Y (1985) Azospirillum as a potential inoculant for Agriculture. Trends in Biotechnology 3: 223-228.

36. Sumner ME (1990) Crop responses to Azospirillum, In: Stewart BA (edn) Advance in soil science, Springer, New York, 53-123.

37. Saikia (2001) Azospirillium Beijernick-plant interaction Boon for sustainable Agriculture. Indian Forming, 6-9.

38. Okon Y, Kapulnik Y (1986) Development and Function of Azospirillum inoculated roots. Plant and soil 90: 3-16.

39. Wong PP, Sternberg NE (1979) Characterization of Azospirillum isolates from nitrogen fixing roots of harvested Sorghum plants. Applied Environmental Microbiology 38 : 1189-1191

40. Tien TM, Gaskins MH, Hubbell DH (1979) Plant growth substances produced by Azospirillum brasilense and their effect on the growth of pearl mille (Pennisetum americanum L) Appl Environ Microbiol 37: 1016-1024.

41. Swaminath $\mathrm{MH}$, Vadiraj BA (1988) Nursery studies on the influence of Azospirillum biofertilizers on the growth and dry matter of forestry species. My forest 24: 289-294

42. Rajendran K, Devaraj P (2004) Biomass and nutrient distribution and their return of Casuarina equisetifolia inoculated with biofertilizers in the farm land. Biomass and Bioenergy 26: 235-249.

43. Kucey RMN (1987) Increased phosphorus uptake by wheat and field beans inoculated with a phosphorus solublizing Penicillium bilaji strain and with vesicular arbuscular mycorrhizal fungi. Appl Environ Microbiol 52: 2699-2703.

44. Stribley DP (1987) Mineral nutrition. Ecophysiology of VAMycorrhizal plants (G.R. Safir ed.,), CRC Press, Boca Raton, Florida.

45. Abbott LK, Robson AD (1982) The role of vesicular arbuscular mycorrhiza fungi in agriculture and selection of fungi for inoculation. Aust J Agric Res 33: $389-408$

46. Verma RK, Jamaluddin R (1995) Association and activity of arbuscular mycorrhizae of teak (Tectona grandis) in central India. Indian forester 121 533-539.

47. Howeler RH, Edwards DG, Asher CJ (1981) Application of the flowering solution culture techniques to studies involving mycorrhizae. Plant and Soil 59: $179-183$

48. Ramamoorthy A (1982) Studies on interaction between phosphobacteria and nitrogen fixing microorganisms in relation to production of peart mille (Pennisetum americamum). M.Sc.(Ag). Thesis, Tamilnadu Agricultura University, Coimbatore.

49. Gaur AC (1990) Phosphate solubilising microorganisms as biofertilizers Omega scientific publishers.

50. Gunjal SS, Patil PL (1992) Mycorrhizal control of wilt in Casuarinas. Agroforestry Today 4: 14-15

51. Young CC, Juang TC, Chao CC (1988) Effects of Rhizobium and vesiculararbuscular mycorrhiza inoculations on nodulation, symbiotic nitrogen fixation and soybean yield in subtropical-tropical fields. Biology and Fertility of Soils 6: $165-169$.

52. McArthur DAJ, Knowles NR (1993) Influence of Vesicular arbuscula mycorrhizal fungi on the response of potato to phosphorus deficiency. Plant physiology 101: 147-160

53. Singh M, Jagadish Singh, Kalyan Singh (1983) Effect of phosphorous and bio fertilizers on chlorophyll content of leaves and laghaemoglobin content of fresh nodules in kharif grain legumes. Indian Journal of Agronomy 28: 229 234

54. Sekar I, Vanangamudi K, Suresh K (1995) Effects biofertilizers on the seedling biomass VAM colonization, enzyme activity and phosphorous uptake in the shola tree species. Myforest 31: 21-26. 